\title{
LAS BUSUR UNTUK PENCIPTAAN KARYA 3 DIMENSI PERMUKAAN LENGKUNG BAHAN AS STAINLESS STEEL BENTUK OVAL
}

\author{
Miky Endro Santoso ${ }^{1}$ \\ (Fakultas Seni Rupa dan Desain, Universitas Kristen Maranatha, Bandung, mikypatung@yahoo.com, \\ miky.es@art.maranatha.edu, 087722596009) \\ Elliati Djakaria ${ }^{2}$ \\ (Fakultas Seni Rupa dan Desain, Universitas Kristen Maranatha, Bandung, elliatidjakaria@yahoo.co.id, 0811220460)
}

\begin{abstract}
This study uses an experimental-descriptive practical research method, focused on the use of arc welding techniques with stainless steel shaft for the creation of 3-dimensional works with curved surfaces. Application for oval form case studies. The purpose of this research is to identify the materials and equipment needed in the welding process with arc welding techniques; know the stages of implementing the creation process starting from preparation, workmanship, and finishing. This experimental-descriptive practice research method was chosen because the researcher was directly involved in the welding experiment process, felt firsthand the level of difficulty and various obstacles in the creation process, and analyzed the results during the research, accompanied by documentation and recording. This research resulted in a 3-dimensional work of art made of stainless steel axles with oval-formed curved surfaces and research conclusions, one of which occurred shrinking the form of the welding results. The results of this research could potentially increase the diversity of art and craft products that use stainless steel axles, such as sculptures, furniture, metal crafts, and so on.
\end{abstract}

Keywords: arc welding, metal craft, sculpture, stainless steel shaft

ABSTRAK

Penelitian ini menggunakan metode riset praktik eksperimental-deskriptif, difokuskan pada penggunaan teknik las busur dengan bahan as stainless steel untuk penciptaan karya 3 dimensi dengan permukaan lengkung. Penerapan untuk studi kasus bentuk oval. Tujuan riset ini adalah mengidentifikasi material dan peralatan yang diperlukan dalam proses pengelasan dengan teknik las busur; mengetahui tahapan pelaksanaan proses penciptaan mulai dari persiapan, pengerjaan dan finishing. Metode riset praktik eksperimental-deskriptif ini dipilih karena peneliti terlibat langsung dalam proses eksperimen pengelasan, merasakan secara langsung tingkat kesulitan dan berbagai kendala dalam proses penciptaan serta menganalisis hasil selama riset, disertai dokumentasi dan pencatatan. Riset ini menghasilkan sebuah karya seni 3 dimensi berbahan as stainless steel dengan permukaan lengkung berbentuk oval dan simpulan riset, salah satunya terjadi penyusutan bentuk pada hasil pengelasan. Hasil riset ini berpotensi dapat menambah keberagaman produk seni dan kriya yang menggunakan bahan as stainless steel, seperti patung, furnitur, kriya logam, dan sebagainya.

Kata Kunci: as stainless steel, kriya logam, las busur, patung 


\section{PENDAHULUAN}

Pesatnya perkembangan bentuk 3 dimensi disertai dengan kecenderungan gaya, bentuk, bahan, dan teknik, telah merangsang bermunculan berbagai kecenderungan karya 3 dimensi yeng kekinian (kontemporer). Salah satunya adalah penerapan bahan stainless steel pada bentuk 3 dimensi dengan permukaan melengkung. Sebut saja seperti karya Jeff Koons dan Anish Kapoor. Bentuk karya dua seniman internasional ini beberapa di antaranya menggunakan bahan stainless steel pada bentuk 3 dimensi dengan permukaannya melengkung. Bentuk 3 dimensi dengan permukaan melengkung berbahan stainless steel ini juga ada yang diterapkan pada furniture dan benda-benda fungsional lainnya.

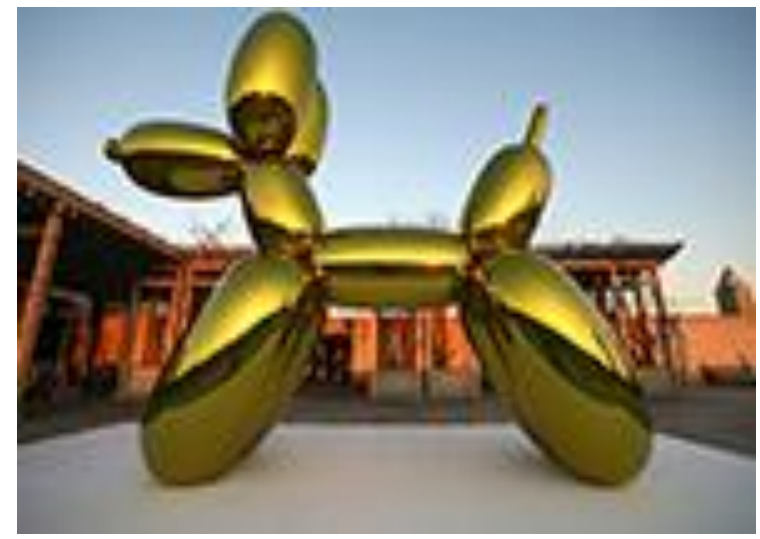

Gambar 1. Karya pematung Jeff Koons, Balloon Dog (Yellow), 2008, di the Cantor Roof Garden-the

Metropolitan Museum of Art, New York. (sumber: https://www.nytimes.com/2008/04/22/arts/design/22koo n.html)

Jika pengolahan bahan stainless steel sebatas bentuk-bentuk geometri dengan permukaan lurus mendatar, maka tidak banyak menimbulkan kendala pada bagian teknik pengerjaannya. Namun karena tuntutan ide/gagasan yang lebih unik, maka pengolahan bahan stainless steel tidak sebatas bentuk geometri saja, namun merambah ke bentuk organik lengkung, khususnya pada permukaan melengkung bentuk 3 dimensi. Hal ini tentunya menjadi tantangan tersendiri bagi artis, artisan, maupun desainer untuk dapat mewujudkannya.

Dikaitkan dengan perkembangan pendidikan seni rupa dan desain di Indonesia, khususnya dalam hal penciptaan karya 3 dimensi dalam bentuk apapun, maka penerapan bahan stainless steel ini bisa dikatakan sangat jarang. Apalagi jika penerapan bahan stainless steel tersebut diaplikasikan pada permukaan melengkung pada wujud 3 dimensi (misal seperti bentuk bola, oval, dan bentuk organik lengkung lainnya). Hal ini dikarenakan stainless steel adalah merupakan baja tahan karat yang memiliki sifat sangat keras dan titik didih yang sangat tinggi. Ini salah satu faktor yang menyebabkan stainless steel sulit untuk diolah menjadi bentuk 3 dimensi khususnya dengan permukaan yang melengkung dan organik.

Kontribusi riset ini mencakup bidang pendidikan, yaitu dapat menambah khasanah teknik penciptaan karya 3 dimensi, khususnya yang berbentuk lengkung organik dengan menggunakan bahan as stainless steel, sehingga berpotensi menambah keragaman dan keunikan bentuk 3 dimensi. Di bidang pengabdian masyarakat, teknik las busur dengan bahan as stainless steel ini, sangat berpotensi untuk dikembangkan pada masyarakat yang memiliki usaha bidang pengelasan sehingga dapat menambah keragaman produk yang dihasilkan, yang secara tidak langsung dapat menambah pendapatan dan kesejahteraan masyarakat itu sendiri. Di bidang penelitian lanjutan, dapat dikembangkan ke arah penelitian dengan teknik lain selain teknik las busur, eksplorasi bentuk organik lainnya yang lebih unik dan kompleks, maupun cara pengaplikasian bahan as stainless steel yang lebih bervariasi. 
Sedangkan alasan penentuan bentuk oval pada kasus studi kali ini adalah terinspirasi dari motif batik kawung yang berbentuk oval, bentuknya mewakili bentuk dengan permukaannya lengkung (selain bentuk bola, dan bentuk lainnya), mudah pembuatan modelnya (pada tahap persiapan) sehingga tidak mengganggu fokus utama penelitian yakni tentang teknik las busur dalam penciptaan karya 3 dimensi, bentuknya unik dan dapat didisplai dengan 2 kemungkinan yaitu displai dengan posisi oval vertikal dan oval horizontal.

\section{TINJAUAN PUSTAKA}

\section{a. Pengertian Pengelasan}

Pengelasan (welding) adalah salah satu teknik penyambungan logam dengan cara mencairkan sebagian logam induk dan logam pengisi dengan atau tanpa tekanan. Proses pengelasan adalah proses penyambungan bahan yang menghasilkan peleburan bahan dengan memanasinya hingga suhu yang tepat (prinsip-prinsip proses difusi) dengan atau tanpa pemberian tekanan dan dengan atau tanpa pemakaian bahan pengisi (filler metal). Pengelasan (welding) didefinisikan oleh DIN (Deutsche Industrie Normen) adalah ikatan metalurgi pada sambungan logam atau logam paduan yang dilaksanakan dalam keadaan lumer atau cair. Dengan kata lain, pengelasan adalah suatu proses penyambungan logam menjadi satu akibat panas atau tanpa pengaruh tekanan atau dapat juga didefinisikan sebagai ikatan metalurgi yang ditimbulkan oleh gaya tarik menarik antar logam. Penyambungan bisa dengan atau tanpa bahan tambah yang sama atau berbeda titik cair maupun strukturnya (Alip M, 1989). Kelebihan sambungan las adalah konstruksi ringan, dapat menahan kekuatan yang tinggi, mudah pelaksanaannya, serta cukup ekonomis. Namun kelemahan yang paling utama adalah terjadinya perubahan struktur mikro bahan yang dilas, sehingga terjadi perubahan sifat fisik maupun mekanis dari bahan yang dilas. Selain itu kelemahan dari pengelasan diantaranya adalah timbulnya lonjakan tegangan yang besar disebabkan oleh perubahan struktur mikro pada daerah las yang menyebabkan turunnya kekuatan bahan dan akibat adanya tegangan sisa dan adanya cacat dan retak akibat proses pengelasan (Nasrul et al., 2016).

\section{b. Pengelasan Busur}

Pengelasan busur (arc welding) istilah lengkapnya adalah las busur listrik elektroda terlindung atau SMAW (Shielded Metal ArC Welding) merupakan pengelasan menggunakan busur nyala listrik sebagai panas pencair logam. Busur listrik terbentuk diantara elektroda terlindung dan logam induk (Daryanto, 2012). Karena panas dari busur listrik maka logam induk dan ujung elektroda mencair dan membeku bersama (Wiryosumarto \& Okumura, 2000). Proses las busur dilakukan dengan menggunakan energi listrik $(A C / D C)$, energi listrik dikonversi menjadi energi panas dengan membangkitkan busur listrik melalui sebuah elektroda. Busur listrik diperoleh dengan cara mendekatkan elektroda las ke benda kerja (logam) yang akan dilas pada jarak beberapa milimeter, sehingga terjadi aliran arus listrik dari elektroda ke benda kerja, karena adanya perbedaan tegangan antara elektroda dan benda kerja (logam yang akan dilas). Panas yang dihasilkan dapat mencapai $5000^{\circ} \mathrm{C}$, sehingga mampu melelehkan 
elektroda dan logam yang akan disambung untuk membentuk paduan (Bintoro, 1999). Terak atau ampas leburan logam, terbentuk pada hasil pengelasan busur, yang disebabkan oleh fluks elektroda. Ini harus dikupas dengan palu khusus sebelum pengelasan lebih lanjut dapat dilakukan (Mills, 1990).

\section{c. Arus Listrik Pengelasan dan Waktu Pengelasan}

Arus listrik pengelasan (current welding) merupakan parameter las yang langsung mempengaruhi penembusan dan kecepatan pencairan logam induk, makin tinggi arus listrik pengelasan maka makin besar penembusan dan kecepatan pencairannya. Besar arus pada pengelasan mempengaruhi hasil pengelasan, bila arus terlalu rendah maka perpindahan cairan dari ujung elektroda yang digunakan sangat sulit dan busur listrik yang terjadi tidak stabil. Panas yang terjadi tidak cukup untuk melelehkan logam dasar, sehingga menghasilkan bentuk rigi-rigi las yang kecil dan tidak rata serta penembusan pada logam induk kurang dalam. Jika arus terlalu besar, maka akan menghasilkan manik melebar, butiran percikan kecil, penetrasi dalam serta matrik las tinggi (Arifin S, 1997). Waktu pengelasan (welding time) adalah waktu dimana arus listrik dialirkan saat proses pengelasan. Waktu pengelasan sangat singkat antara 450 cycle (0.1-1 detik). Pengaturan waktu pengelasan tergantung dari mesin las resistensi listrik yang digunakan. Pada mesin las sudah tersedia panel pengaturan waktu pengelasan yang ingin dikehendaki, besarnya waktu pengelasan dipengaruhi oleh tebal plat yang dilas dan kuat arus listrik pengelasan, artinya sangat memungkinkan jika arus yang diberikan besar maka waktu pengelasan lebih singkat, jika arus yang diberikan kecil maka waktu pengelasan bisa lebih lama (Ruukki, 2007).

\section{d. Stainless Steel 304}

Baja stainless steel merupakan baja paduan yang mengandung minimal $10,5 \% \mathrm{Cr}$. Hanya sedikit baja stainless steel mengandung lebih dari 30\% Cr atau kurang dari 50\% Fe. Karakteristik khusus baja stainless steel adalah pembentukan lapisan film Kromium Oksida (Cr2O3). Lapisan ini berkarakter kuat, tidak mudah pecah dan tidak terlihat secara kasat mata. Umumnya berdasarkan struktur metalurgi atau perpaduan unsur kimia dan persentase baja, stainless steel dibagi menjadi lima kategori (www.astm.org) yaitu baja martensitic stainless steel, ferritic stainless steel, austenitic stainless steel, duplex stainless steel, dan baja pengerasan endapan (precipitation hardening). Baja tahan karat SS 304 tergolong pada baja austenitic stainless steel. Austenitic stainless steel merupakan baja paduan yang memiliki kandungan $16-26 \% \mathrm{Cr}, 0.75-19.0 \% \mathrm{Mn}, 1-$ $40 \% \mathrm{Ni}, 0.03-0.35 \%$ C, dan kandungan $\mathrm{N}$ sebagai penstabil austenite pada temperatur ruang dan kenaikan temperatur tertentu.

\section{METODE}

Riset ini dilaksanakan dengan menggunakan metode eksperimentaldeskriptif, yakni penelitian secara obyektif melakukan percobaan langsung (proses pengelasan dari bahan as stainless steel) dimana penulis sekaligus pelaku yang melakukan penelitian eksperimen dengan memanipulasi paling sedikit satu veriabel bebas yakni penggunaan bahan as stainless steel (diameter $3 \mathrm{~mm}$ dan $4 \mathrm{~mm}$ ), dan mengontrol 
variabel terikatnya yakni teknik las busur dan bentuk oval (pengelasan pada cetakan oval) yang disertai proses identifikasi, dokumentasi, dan pencatatan berdasarkan fakta-fakta yang ada. Hal ini sesuai dengan pemahaman penelitian eksperimental dan penelitian deskriptif (Gay, 1981). Dan juga sesuai dengan eksplorasi kerja praktik (practice-based research) melalui proses eksperimental yang dapat menghasilkan berbagai kemungkinan dalam penciptaan karya seni (Nuning. W., 2015).

Riset eksperimental-deskriptif ini dilakukan dengan melalui 3 tahap yang berurutan, yaitu tahap persiapan, tahap pengerjaan, dan tahap akhir. Dimulai dari tahap persiapan, yaitu tahap mempersiapkan segala bahan dan peralatan yang nantinya akan digunakan untuk tahap pengerjaan dan tahap akhir. Semua bahan dan peralatan ini nantinya dicatat dan diklasifikasi berdasarkan kesesuaian penggunaan dalam tahap pengerjaan dan tahap akhir pada proses pengelasan untuk penciptaan karya 3 dimensi dari bahan as stainless steel yang berbentuk oval. Berikutnya tahap pengerjaan, yaitu tahap dimulainya eksperimen pengerjaan, dimulai dari 1) pembuatan model,
2) pembuatan cetakan, 3) pengelasan pada cetakan. Pada tahap pengerjaan ini variabel tetapnya adalah teknik las busur dan bentuk oval, sedangkan variabel bebasnya adalah penggunaan elektrode $0,6 \mathrm{~mm}$ dan $2 \mathrm{~mm}$, serta penggunaan as stainless steel diameter $3 \mathrm{~mm}$ dan $4 \mathrm{~mm}$. Tahap akhir adalah tahap assembling dan finishing. Assembling (perakitan) yang dimaksud pada konteks ini adalah pengelasan as stainless steel yang berupa potonganpotongan kecil, yang disempurnakan sambungan lasnya, dilas dari sisi luar betuk oval, sebelum masuk finishing. Finishing atau penyelesaian akhir, pada konteks ini adalah memapras dan mengamplas bentuk as stainless steel agar mudah dipoles dan menciptakan hasil akhir yang mengkilap.

Masing-masing tahap tadi, dianalisis secara sinkronik pertahap agar didapat hasil kesimpulan pertahap yang lebih detail. Selanjutnya untuk keseluruhan tahap (tahap persiapan, tahap pengerjaan, tahap akhir) akan dianalisis secara diakronik agar didapat korelasi dan relevansi untuk keseluruhan tahap pengerjaan penelitian eksperimental ini. 


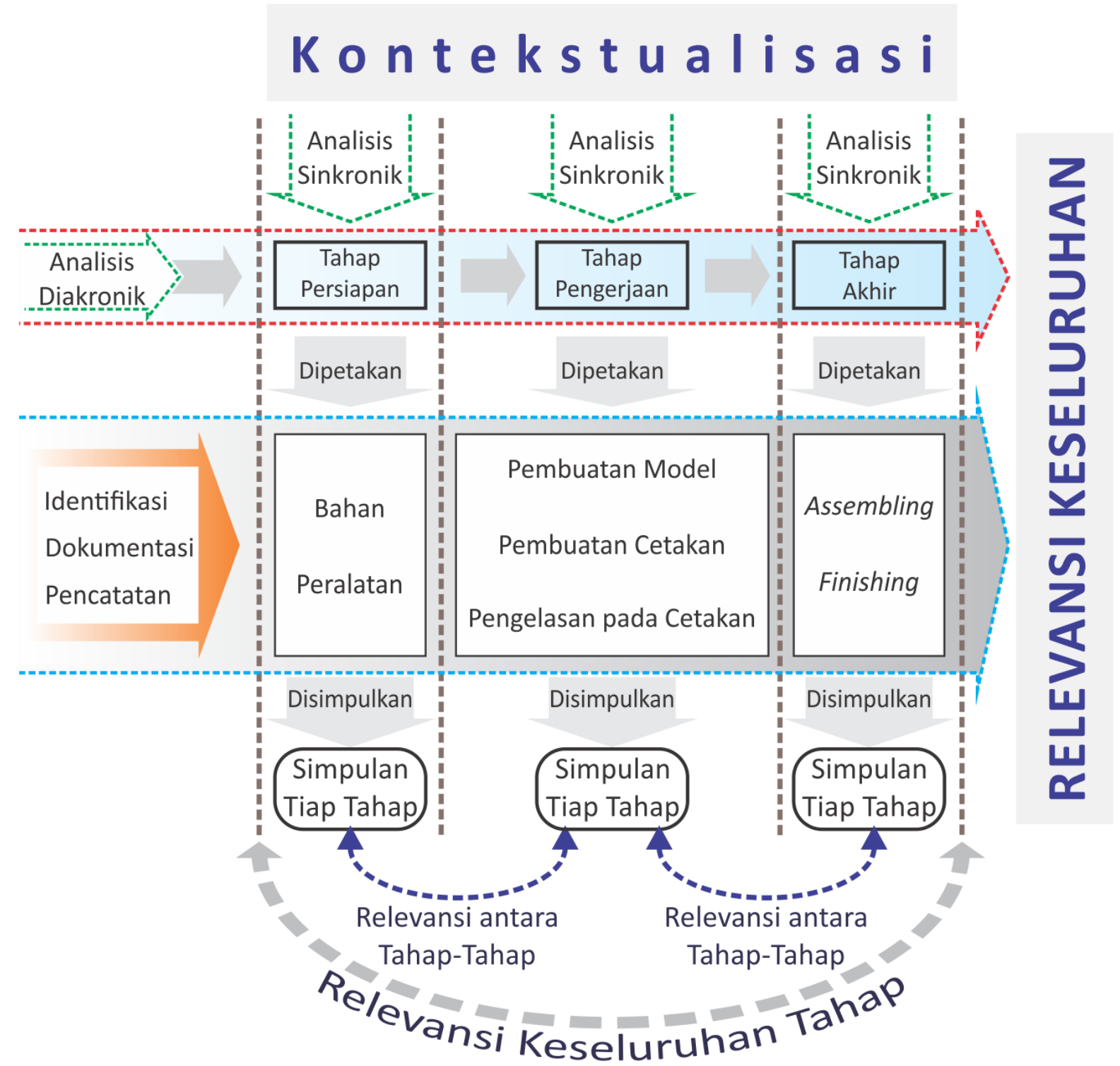

Gambar 4. Kerangka Analisis. (Dokumen pribadi, 2020)

Secara simultan juga dilakukan studi literatur yang diharapkan ada faktor pembanding antara teori dengan prakteknya. Semua langkah-langkah riset tersebut diakhiri dengan suatu tindakan analisis yang kemudian didapatkan hasil penelitian berupa hasil produk dari proses pengelasan busur berupa satu karya seni rupa 3 dimensi dari bahan as stainless steel, temuan-temuan dan simpulan. Kesimpulannya diharapkan dapat memberikan tambahan pengetahuan dan pemahaman mengenai: bahan-bahan dan peralatanperalatan yang diperlukan agar proses teknik las busur dalam penciptaan karya 3 dimensi dengan permukaan lengkung dari bahan as stainless steel dapat berjalan dengan sempurna; tata-cara menggunakan peralatan yang ada beserta cara memanfaatkan dan memadukan bahan-bahan agar proses pengelasan dapat berjalan dengan baik dan efektif; mengetahui tahap-tahap pelaksanaan proses pengelasan as stainless steel mulai dari tahap persiapan 
(bahan, peralatan), tahap pengerjaan (pembuatan model, pembuatan cetakan, pengelasan pada cetakan) dan tahap akhir (assembling, finishing).

\section{A. Tahap Persiapan}

Tahap persiapan adalah segala sesuatu yang harus disediakan dan dipersiapkan agar tahap selanjutnya (tahap pengerjaan dan tahap akhir) dapat berjalan dengan lancar. Pada tahap persiapan ini diklasifikasikan menjadi 2, yaitu:

1. Bahan

Bahan yang dimaksud di sini adalah segala sesuatu yang dapat diolah dan digunakan untuk membantu proses penciptaan karya yang menjadi tujuan hasil dalam riset ini, yaitu karya 3 dimensi dengan permukaan lengkung dari bahan as stainless steel 304.
Karena proses penciptaan karya 3 dimensi ini melalui 5 langkah pengerjaan maka pengelompokan bahan di sini juga menjadi 5 kelompok berdasarkan 5 langkah pengerjaan tadi. 5 langkah pengerjaan tersebut adalah

- Tahap Pengerjaan, terdiri dari 3 langkah:

1) pembuatan model, 2) pembuatan cetakan, 3) pengelasan pada cetakan

- Tahap Akhir, terdiri dari 2 langkah:

4) assembling dan 5) finishing

Adapun identifikasi material berdasarkan 5 langkah pengerjaan (1. Pembuatan Model, 2. Pembuatan Cetakan, 3. Pengelasan Pada Cetakan, 4. Assembling, 5. Finishing) silahkan lihat tabel 1.

\begin{tabular}{|c|c|c|c|c|c|c|}
\hline No. & Nama Bahan & $\begin{array}{l}\text { 1. Pembuatan } \\
\text { Model }\end{array}$ & $\begin{array}{l}\text { 2. Pembuatan } \\
\text { Cetakan }\end{array}$ & $\begin{array}{l}\text { 3. Pengelasan } \\
\text { pada Cetakan }\end{array}$ & 4. Assembling & 5. Finishing \\
\hline 1. & Gypsum & 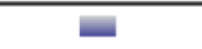 & & & & \\
\hline & Kalsit & = & & & & \\
\hline 3. & Air & = & & & & D \\
\hline 4. & Multipleks & $=$ & & & & \\
\hline & Paku & 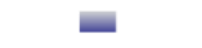 & & & & \\
\hline 6. & Sekrup & $=$ & & & & \\
\hline 7. & Dempul besi & E & & & & \\
\hline 8. & Resin + talek + katalis & & E & & & \\
\hline & Serat kaca & & ש & & & \\
\hline 10. & Wax & & = & & & \\
\hline 11. & Thinner untuk pencuci & & E & & & \\
\hline 12. & Stainless steel round bars $3 \mathrm{~mm}$ & & & $\mathbf{E}$ & E & \\
\hline 13. & Stainless steel round bars $4 \mathrm{~mm}$ & & & = & $\square$ & \\
\hline 14. & As drat $4 \mathrm{~mm}$ & & & $\mathbf{D}$ & & \\
\hline 15. & Elektroda las stainless $1,6 \mathrm{~mm}$ & & & $\mathbf{E}$ & $\square$ & \\
\hline 16. & Elektroda las stainless $2 \mathrm{~mm}$ & & & 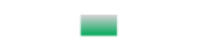 & $\square$ & \\
\hline 17. & Mata gerinda potong stainless & & & $\mathbf{E}$ & $\square$ & ש \\
\hline 18. & Mata gerinda asah & & & & & = \\
\hline 19. & Langsol & & & & & \pm \\
\hline 20. & Mata gerinda amplas susun & & & & & = \\
\hline 21. & Mata gerinda kain jeans poles & & & & & E \\
\hline 22. & Gel pembersih stainless steel & & & & & = \\
\hline 23. & Kain lap & & & & & E \\
\hline
\end{tabular}

Tabel 1. Identifikasi Bahan yang Digunakan Pada 5 Langkah Pengerjaan Dalam Tahap Pengerjaan dan Tahap Akhir. (sumber: dokumen pribadi, 2020) 
2. Peralatan

Peralatan yang dimaksud di sini adalah semua bentuk perkakas atau benda-benda yang dipakai dan digunakan dalam riset ini untuk membantu kelancaran proses penciptaan karya 3 dimensi dengan permukaan lengkung dari bahan as stainless steel 304. Untuk peralatan yang dibutuhkan lihat tabel 2.

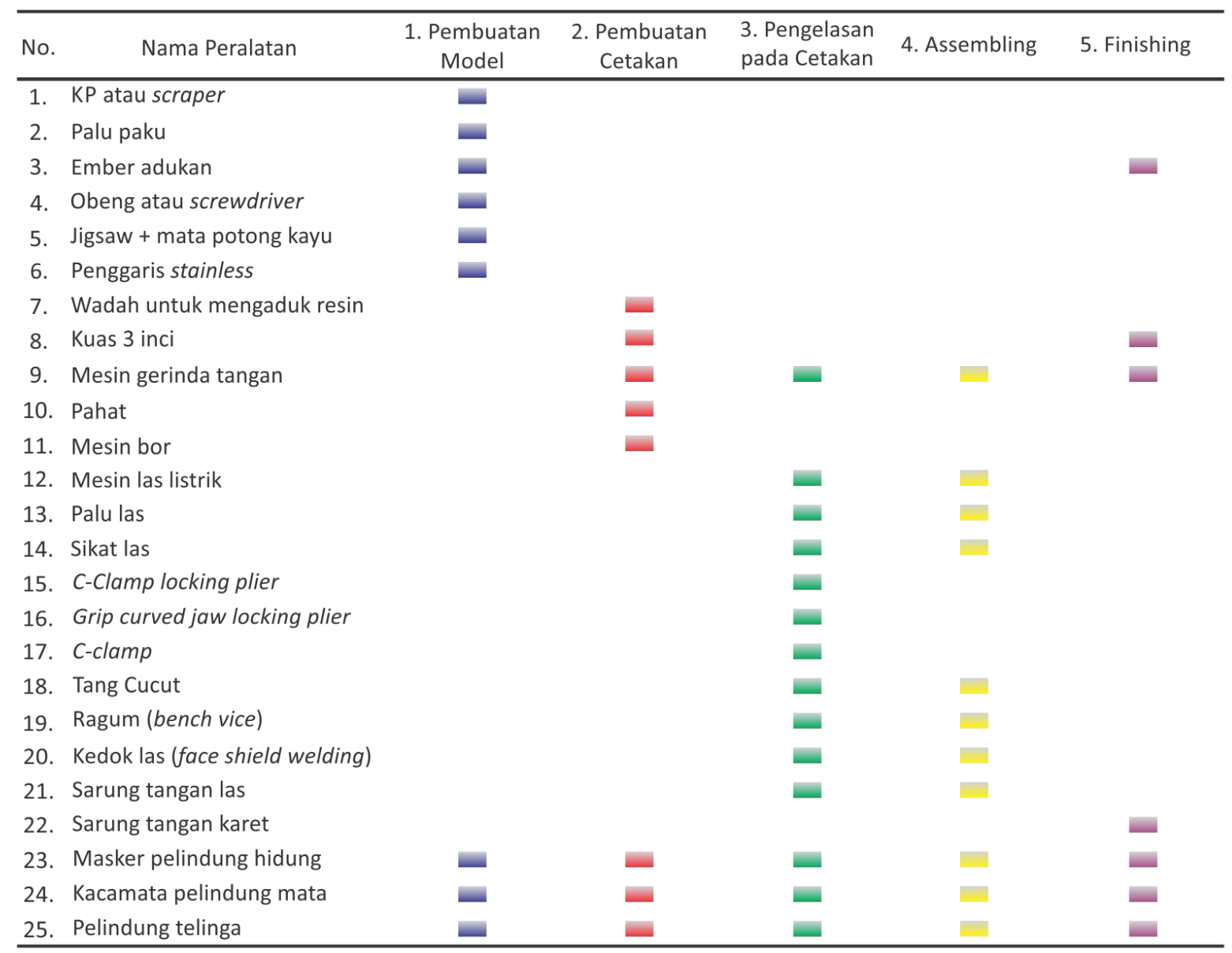

Tabel 2. Identifikasi Nama Peralatan yang Digunakan Pada 5 Langkah Pengerjaan Dalam Tahap Pengerjaan dan Tahap Akhir. (sumber: dokumen pribadi, 2020)

Untuk tahap persiapan ini ada kesamaan dengan tulisan Daniel terkait cara pembuatan patung tiga dimensi (Daniel, 2018). Sama-sama mempersiapkan, mengumpulkan bahan dan material sebelum proses pembuatan. Bedanya kalau Daniel, bahan atau material setelah dibersihkan bisa masuk proses pengelasan. Sedangkan kalau penulis, harus membuat model terlebih dulu untuk dibuat cetakan fiberglass sebagai panduan bentuk oval.

\section{B. Tahap Pengerjaan}

Tahap pengerjaan adalah tahap mulai melakukan proses mengerjakan sesuatu yang berhubungan dengan riset yang sedang dikerjakan, yaitu mengerjakan teknik las busur dengan bahan as stainless steel 304 untuk menciptakan karya 3 dimensi dengan permukaan lengkung, studi kasus: bentuk oval. Pengerjaannya sendiri dilakukan dari 1) pembuatan model, 2) pembuatan cetakan, dan 3) pengelasan pada cetakan. 


\section{Pembuatan Model}

Pembuatan model yang berupa bentuk oval dengan permukaan lengkung dapat dipilah menjadi 2 langkah pengerjaan yang berurutan:

\section{Pertama:}

Membuat kerangka oval dari bahan multiplek. Mulai dari membuat pola oval di komputer dengan ukuran yang sudah ditentukan, selanjutnya pola tersebut dicetak di kertas dengan ukuran 1:1 untuk dijadikan pola potong untuk multiplek. Setelah multiplek dipotong-potong mengikuti pola, berikutnya menyusun multiplek tadi menjadi konstruksi panduan untuk memplester bentuk oval.

\section{Kedua:}

Memplester adonan gypsum (calcium sulfate) dan kalsit (calcium carbonate) membentuk oval. Mulai dari membuat adonan gypsum dan kalsit dengan perbandingan 1:1. Dalam kondisi kering, adonan diaduk hingga rata, dan sedikit demi sedikit dicampur air hingga tercapai adonan yang bisa diplester, tidak terlalu encer, dan tidak terlalu kental. Adonan diplester sedikit demi sedikit pada konstruksi panduan multiplek tadi hingga terbentuk wujud ovalnya. Dan agar tercapai bentuk oval yang halus dan rata, digunakan penggaris stainless yang bisa dilengkungkan, untuk meratakan permukaan dengan dipapras secara perlahan dan bertahap hingga tercapai bentuk oval yang diinginkan.

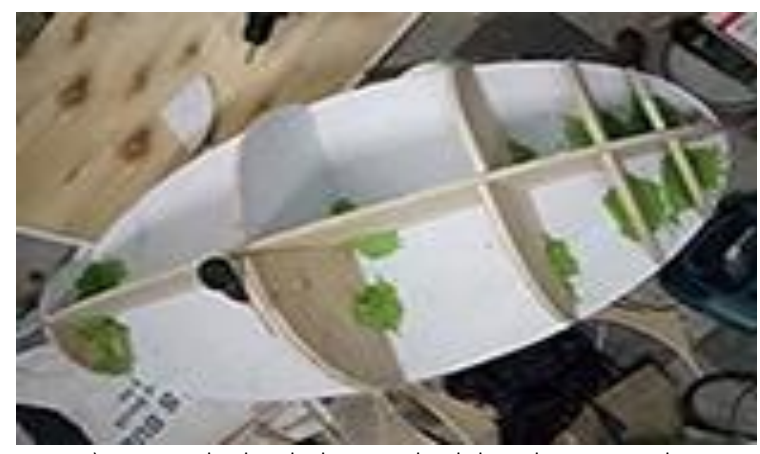

1.a) Konstruki dari bahan multiplek, sebagai panduan bentuk oval (dokumen pribadi 2020)

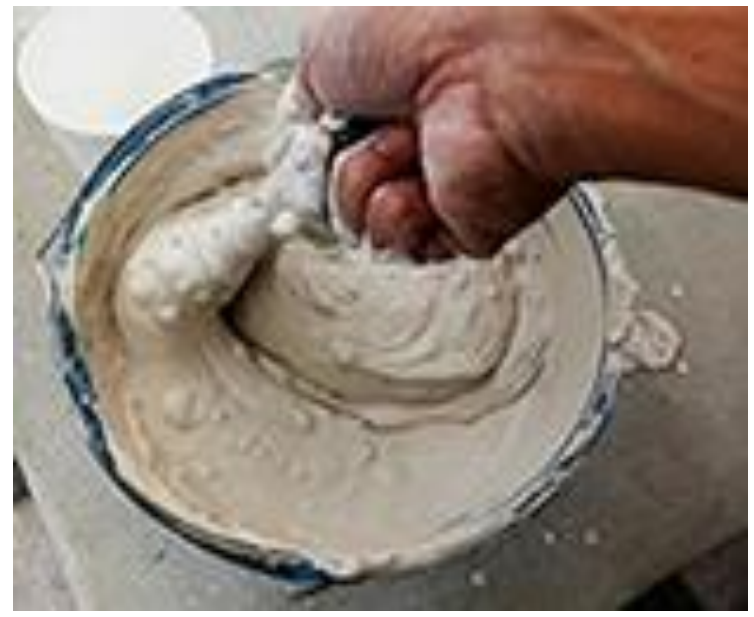

1.b) Membuat adonan gypsum dan kalsit untuk memplester adonan menjadi bentuk oval (dokumen pribadi 2020)

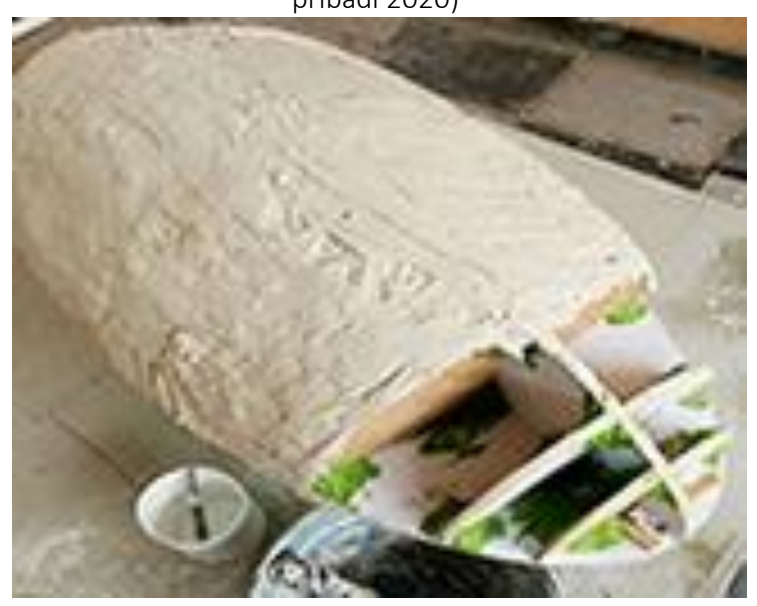

1.c) Memplester adonan menjadi bentuk oval (dokumen pribadi 2020)

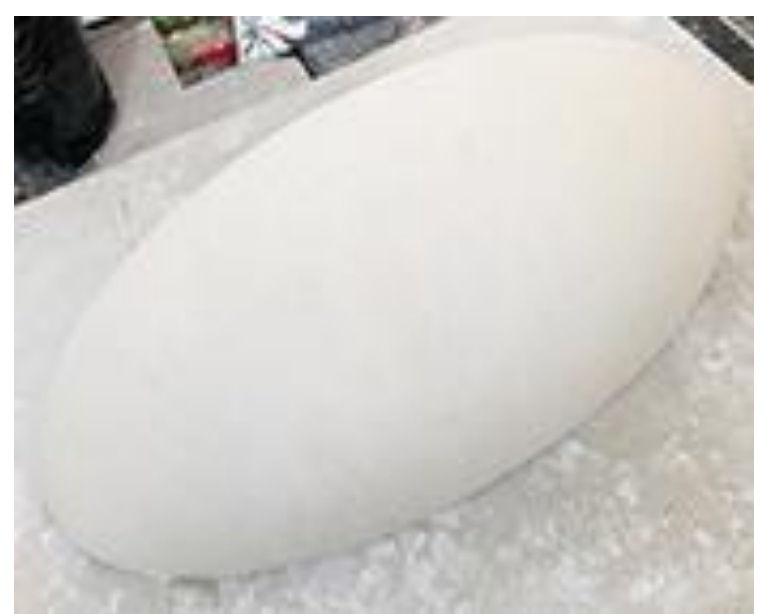

1.d) Bentuk oval yang sudah dihaluskan menggunakan penggaris stainless (dokumen pribadi 2020) 


\section{Pembuatan Cetakan}

Setelah model berbentuk oval selesai dibuat, selanjutnya masuk tahap pembuatan cetakan. Proses pembuatan cetakan ini dipilah menjadi 2 langkah pengerjaan yang pelaksanaannya berurutan.

\section{Pertama:}

Memplester adonan resin dan serat kaca pada permukaan model oval. Proses pemlesteran diawali dengan mengolesi model dengan wax agar saat cetakan dilepas dari model tidak mengalami kesulitan. Selanjutnya dioles adonan resin yang sudah dicampur talek dan katalis hingga rata dan bertahap satu lapis. Lapis kedua hingga ketiga yang dilakukan secara bertahap dan masing-masing tahap selalu disertakan satu lembar serat kaca (fiberglass). Karena ada tiga tahap pelapisan (tahap kedua sampai keempat) berarti ada tiga lembar serat kaca yang disertakan dalam pembuatan cetakan. Hal ini dilakukan agar saat cetakan terkena panas dari proses pengelasan di dalam cetakan, cetakan tetap kuat dan tidak mudah pecah.

\section{Kedua:}

Membuka cetakan dan memisahkan cetakan dari model oval. Tahap ini dimulai dari memahat cetakan resin dan serat kaca tadi agar lepas dari alas tempat model oval berada. Karena cukup lengket, walaupun sudah menggunakan wax, maka dibarengi dengan pemotongan cetakan yang berlebih dengan menggunakan mesin gerinda. Setelah cetakan bisa lepas dari alasnya, selanjutnya usaha mengeluarkan model dari dalam cetakannya. Jika cukup sulit, bisa dibantu dengan alat pahat untuk mencongkelnya. Setelah model bisa dikeluarkan, permukaan dalam cetakan langsung dirapihkan untuk digunakan dalam proses berikutnya yaitu pengelasan pada cetakan.

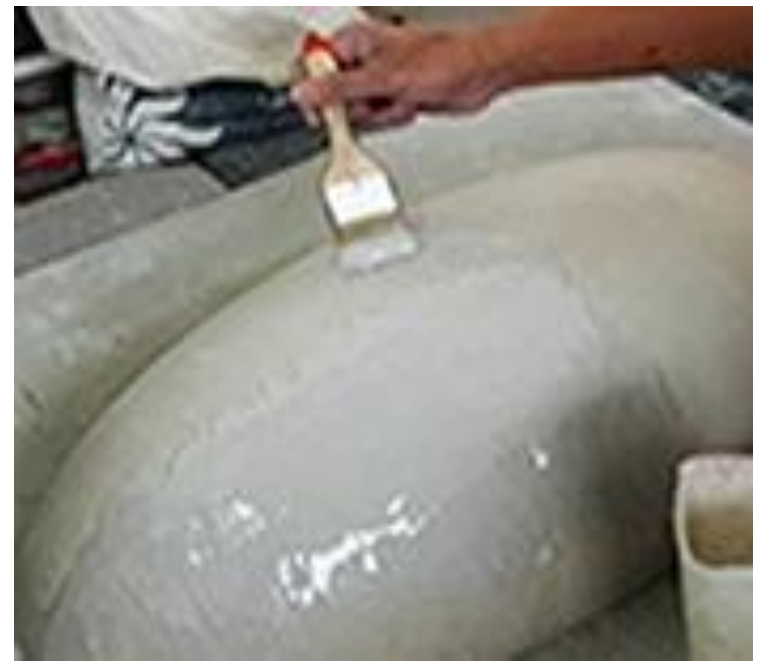

2.a) Pemlesteran adonan resin, talek, dan katalis di lapisan pertama pada permukaan bentuk oval (dokumen pribadi, 2020).

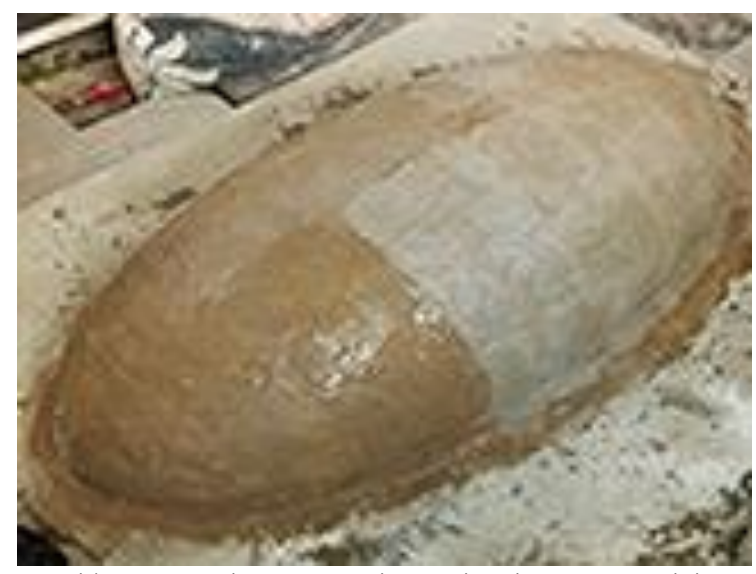

2.b) Proses pelapisan cetakan, ada 3 lapis yang selalu disisipkan lembaran serat kaca (dokumen pribadi, 2020).

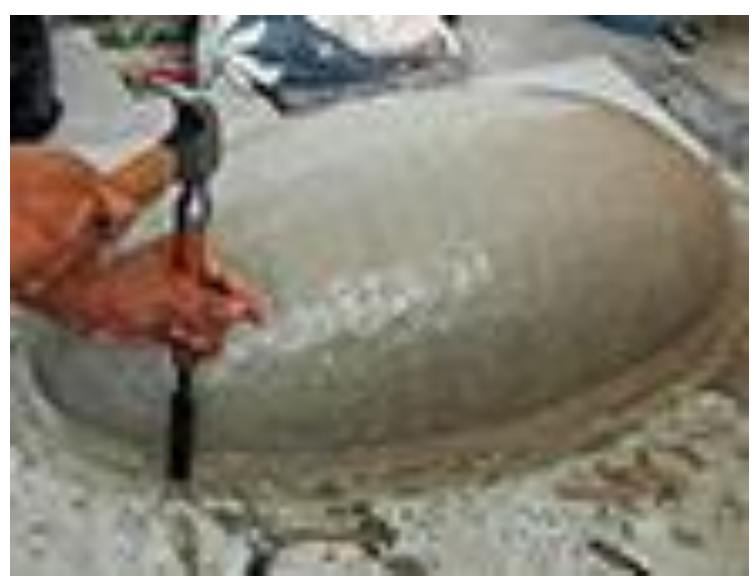

2.c) Pelepasan cetakan dari alas. Jika sulit dilepas dapat menggunakan alat pahat dan palu (dokumen pribadi, 2020) 


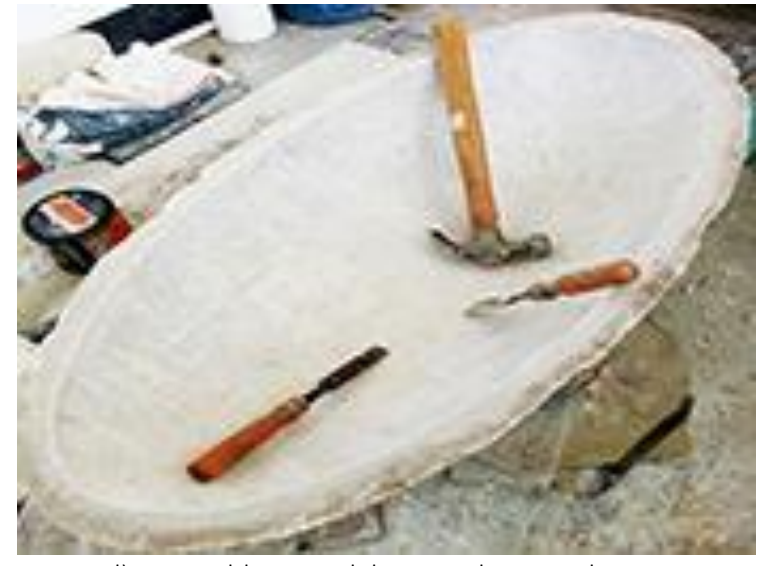

2.d) Merapihkan sisi dalam cetakan untuk proses pengerjaan tahap berikutnya (dokumen pribadi, 2020).

\section{Pengelasan Pada Cetakan}

Ketika cetakan sudah dipersiapkan dan sisi dalamnya sudah dirapihkan, selanjutnya masuk tahap pengelasan pada cetakan. Karena sisi dalam cetakan tersebut permukaannya melengkung, maka bahan as stainless steel harus dibengkokan sedikit dan dipotong kecilkecil sekitar $2 \mathrm{~cm}$ agar mudah dilas dan hasil lasnya sesuai dengan permukaan lengkung tersebut. Selanjutnya proses pengelasan as stainless steel pada sisi dalam cetakan dimulai, awalnya dari tengah dulu, selanjunya secara bertahap menyebar ke luar sampai batas cetakan. Setelah selesai melakukan pengelasan sampai batas-batas tepi cetakan, proses pengeluaran stainless steel dari cetakan pun siap dilakukan. Dan mulai masuk ke tahap akhir.

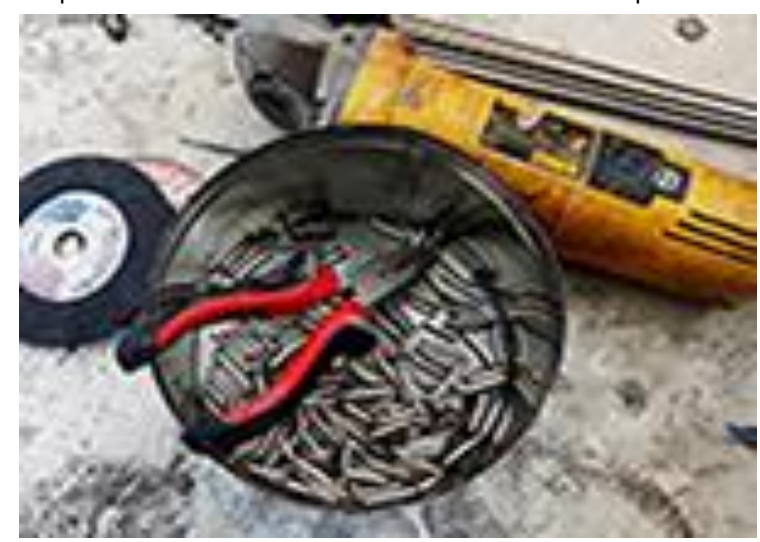

3.a) Bahan yang akan dilas, as stainless steel 304 yg sudah dipotong dan dibengkokan (dokumen pribadi 2020).

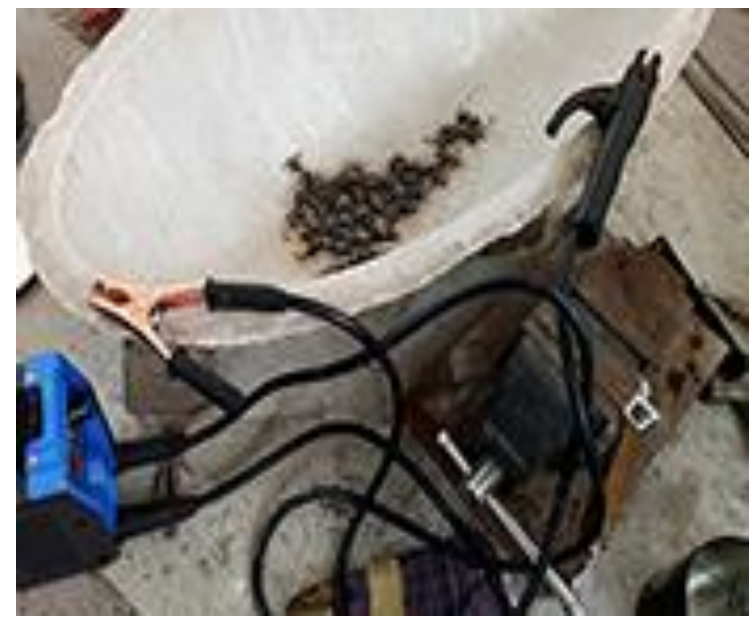

3.b) Proses pengelasan dimulai dari tengah, sedikit demi sedikit menyebar ke tepi luar (dokumen pribadi 2020).

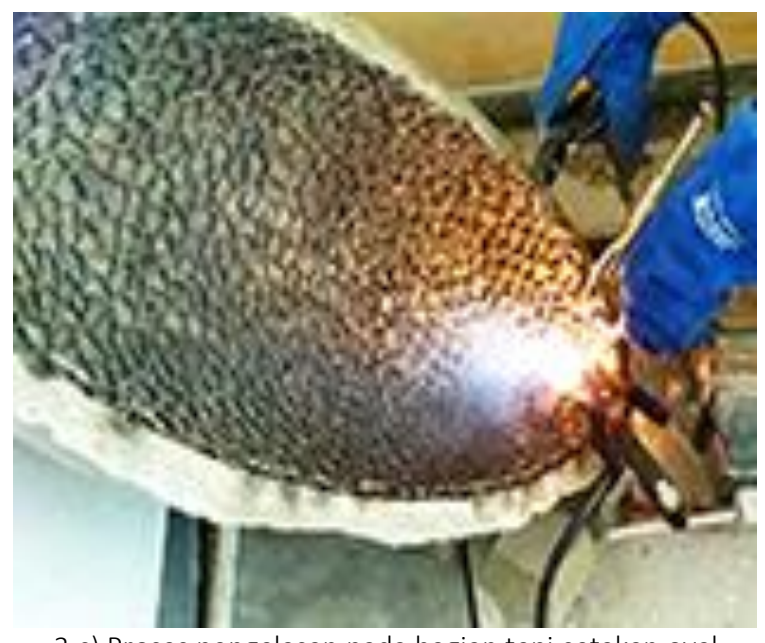

3.c) Proses pengelasan pada bagian tepi cetakan oval (dokumen pribadi 2020).

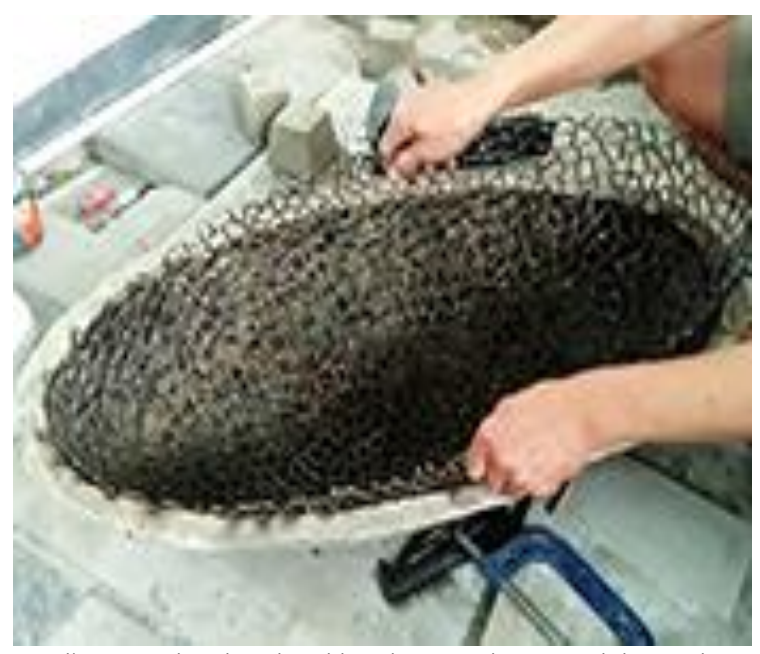

3.d) Mengeluarkan hasil las dari cetakan untuk lanjut ke tahap selanjutnya (dokumen pribadi 2020). 


\section{Tahap Akhir}

\section{Assembling}

Perakitan atau assembling, yang dimaksud di sini adalah menyempurnakan sambungan-sambungan dari potongan as stainless steel yang kecil, yang semula sudah disambung pada pengelasan pada cetakan, namun kualitas lasnya hanya sekedar nempel. Untuk perakitan ini, kualitas lasnya disempurnakan pada bagian pertemuan masing-masing potongan as stainless steel agar karya oval menjadi lebih kuat dan kokoh. Selain itu agar hasil las pada perpotongan tadi ketika dipapras menggunakan mesin gerinda, hasilnya tetap bagus dan sambungan tetap kuat. Namun dampak dari pengelasan ulang pada proses perakitan ini, karya oval menjadi berubah warna hitam gosong akibat terkena panas yang cukup banyak. Setelah pengelasan ulang dirasa cukup rata dan sempurna, maka selanjutnya masuk ke tahap finishing.

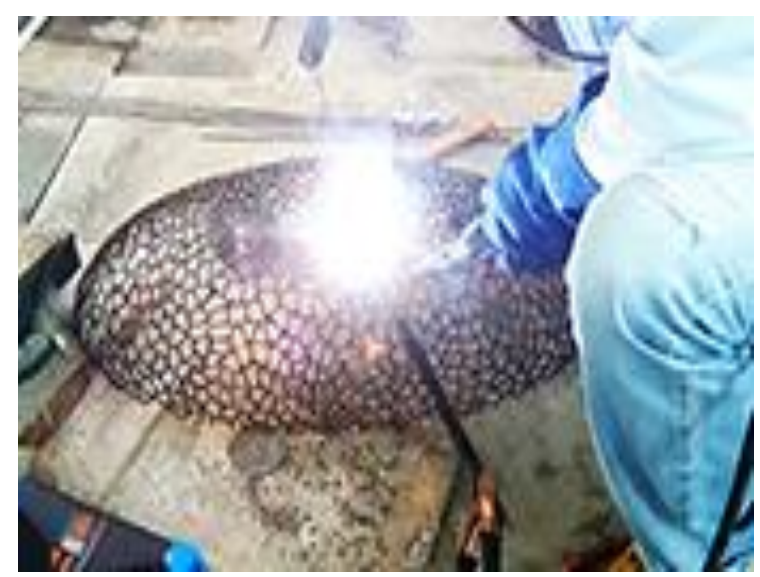

4.1.a) Perakitan dengan melakukan pengelasan dari sisi luar, menyebar ke semua permukaan (dokumen pribadi, 2020).

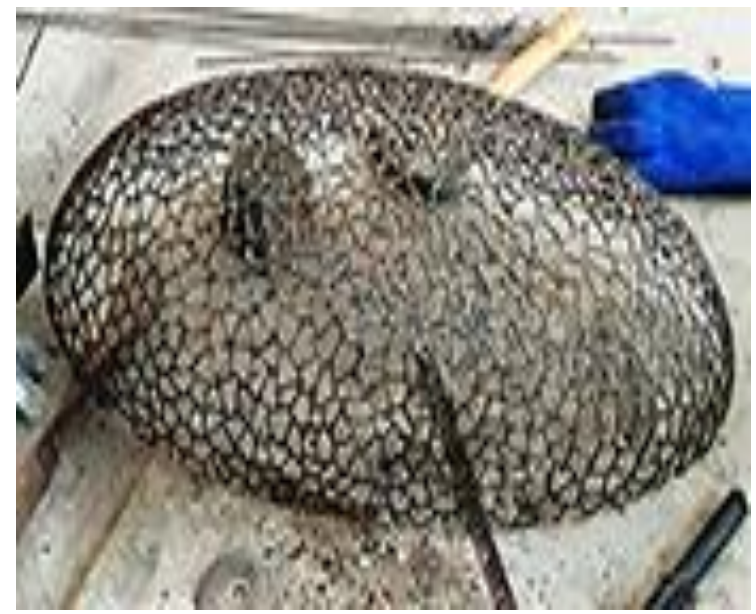

4.1.b) Pengelasan sisi luar telah selesai, karya menjadi hitam gosong, siap masuk tahap finishing (dokumen pribadi, 2020).

\section{Finishing}

Menyelesaikan tahap paling akhir pada proses penciptaan karya 3 dimensi berbentuk oval dari bahan as stainless steel ini, tidaklah sederhana seperti yang dibayangkan. Namun tetap harus dilakukan dengan beberapa langkah penyelesaian. Dimulai dari membersihkan warna hitam gosong beserta terak atau ampas leburan logam bekas pengelasan yang menempel pada bahan as stainless steel, dilanjutkan proses pemaprasan permukaan bahan as stainless steel agar lebih datar sehingga saat dipoles hasilnya lebih maksimal. Pemaprasan ini menggunakan ukuran mata gerinda abrasif dari 80 hingga 220. Dilanjutkan dengan proses pemolesan permukaan lengkung as stainless steel agar nampak lebih mengkilap dengan menggunakan ukuran mata gerinda abrasif dari 220 hingga 600 yang dipasang di mesin gerinda (Verhelst, 1988). Tahap akhir, mesin gerindanya menggunakan mata gerinda kain jeans poles dan batu poles hijau (merk yang populer di masyarakat adalah langsol). 


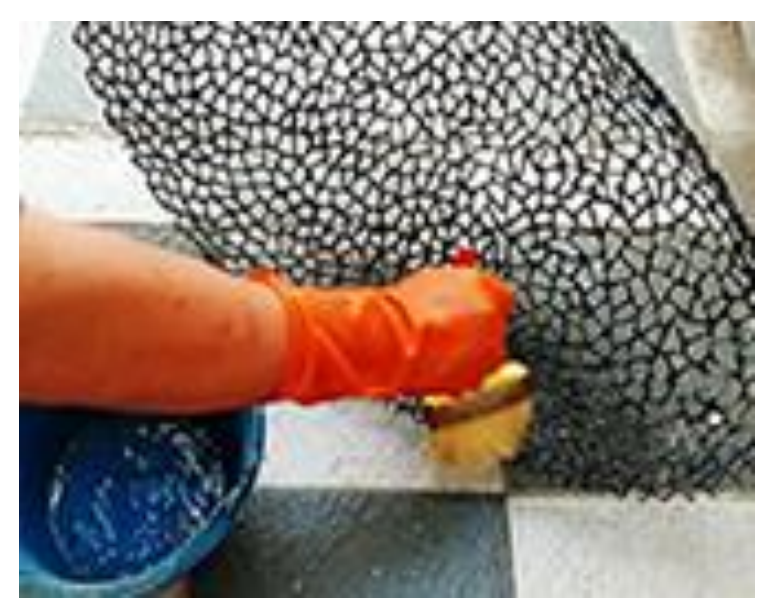

4.2.a) Pembersihan hasil las yang gosong dengan gel pembersih stainless steel (dokumen pribadi, 2020).

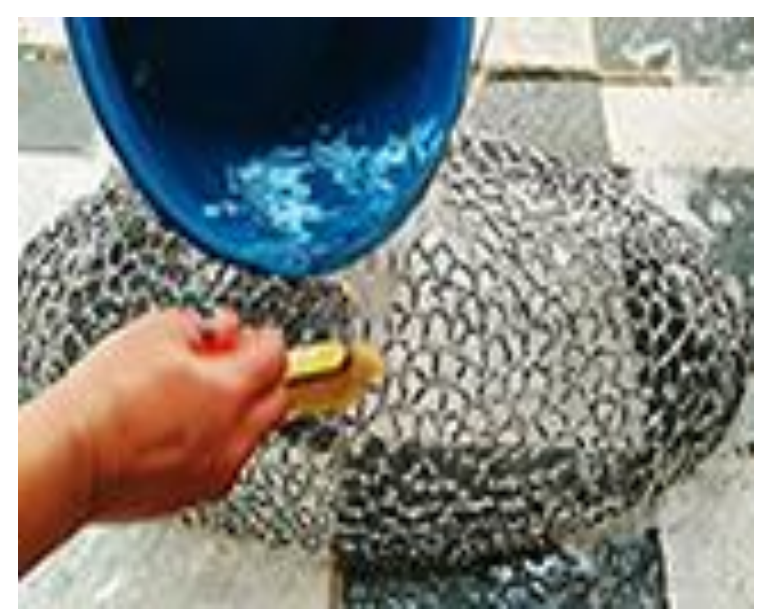

4.2.b) Selanjutnya gel pembersih, dibersihkan dengan air secara berulang hingga bersih keseluruhan (dokumen pribadi, 2020).

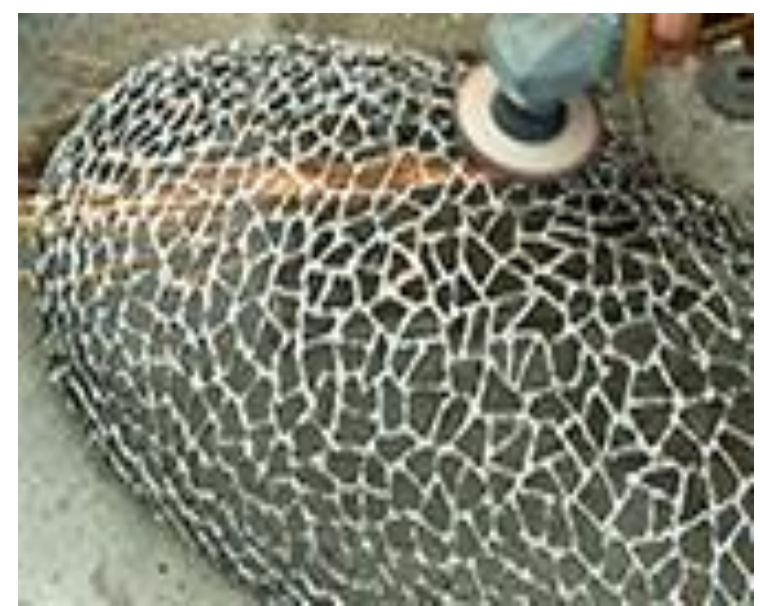

4.2.c) Memapras permukaan oval dengan mata gerinda asah dan mata gerinda amplas susun (dokumen pribadi, 2020).

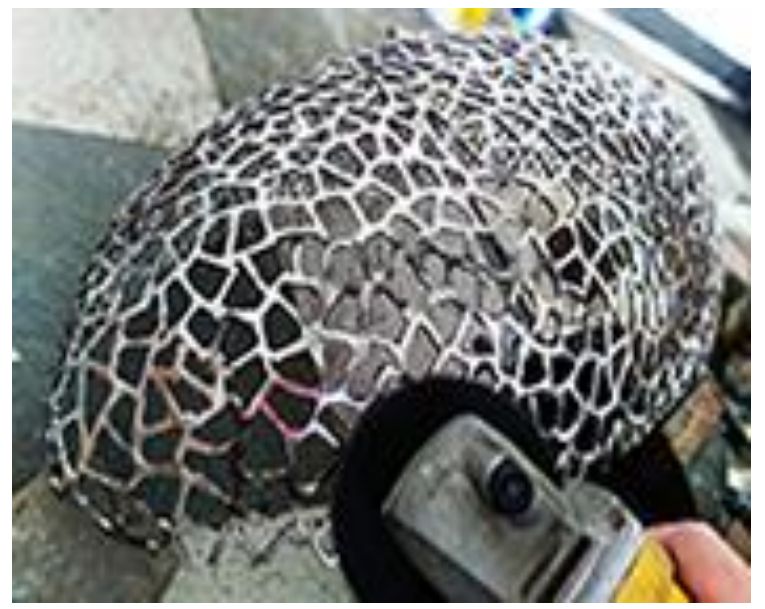

4.2.d) Memoles permukaan oval dengan langsol dan mata gerinda kain jeans poles (dokumen pribadi, 2020).

\section{ANALISIS DAN PEMBAHASAN}

Analisis dan temuan pada tahap persiapan:

Bahan yang digunakan ada yang bisa digunakan lebih dari 1 langkah pengerjaan, seperti penggunaan bahan: air stainless steel round bar $3 \mathrm{~mm}$, stainless steel round bar $4 \mathrm{~mm}$, elektroda las stainless $1,6 \mathrm{~mm}$, elektroda las stainless $2 \mathrm{~mm}$, dan mata gerinda potong. Untuk peralatan yang digunakan ada yang bisa digunakan lebih dari 1 langkah pengerjaan, seperti peralatan: ember adukan, kuas 3 inci, mesin gerinda tangan, mesin las listrik, palu las, sikat las, tang cucut, ragum (bench vice), kedok las (face shield welding), sarung tangan las, masker pelindung hidung, kacamata pelindung, dan pelindung telinga.

Analisis dan temuan pada tahap pengerjaan: Pembuatan model:

Penggunaan konstruksi multiplek sebagai struktur pemandu pembentukan oval untuk teknik plester adonan gypsum dan kalsit adalah sangat membantu memudahkan pembentukan oval itu sendiri, terutama saat proses menghaluskan permukaan dengan bantuan alat penggaris stainless yang dilekungkan. Pembentukan oval jadi lebih mudah dan terarah. Pembuatan adonan 
gypsum + kalsit, disarankan dalam kondisi kering dahulu, di aduk rata dengan menggunakan KP. Setelah dirasa cukup rata, baru selanjutnya dicampur dengan air. Hasil yang didapat jauh lebih mudah rata jika dibandingan kalau mencampurnya dalam kondisi basah dahulu (sudah tercampur air). Fungsi dempul plastik saat membuat konstruksi multiplek adalah membantu terciptanya konstruksi yang lebih kuat dan kokoh, sehingga saat proses memplester adonan, konstruksi multiplek tersebut tidak goyah. Membuat pola oval skala 1:1 dulu pakai vector di komputer, kemudian dicetak di kertas, dan kertas tersebut ditempel di multiplek yang akan dipotong, akan sangat membantu proses pemotongan multiplek untuk dijadikan struktur pemandu bentuk oval.

\section{Pembuatan cetakan:}

Penggunaan wax, sebagai pelapis model oval yang akan dibalur cetakan resin, sebaiknya diberikan cukup banyak agar saat proses pelepasan model dengan cetakan bisa lebih mudah lagi. Pembuatan adukan resin, talek, dan katalis ini disarankan sedikit demi sedikit, misal sekitar $120 \mathrm{ml}-240 \mathrm{ml}$ (seukuran gelas air mineral), hal ini agar adonan yang diaduk dicampur katalis dengan ukuran tertentu sehingga menjadi cepat kering, dan tidak ada adonan resin yang terbuang, dan pengolesannya pun tidak banyak yang meluber hingga ke bawah alas cetak. Penggunaan cairan thinner di sini sangat penting untuk membersihkan kuas agar kuas bisa digunakan berulang-ulang. Dengan cara kuas langsung dibersihkan dengan thinner sesaat setelah kuas digunakan untuk mengoles adonan resin pada proses membuat cetakan.

\section{Pengelasan pada cetakan:}

Penggunaan bahan as stainless steel (stainless steel round bar) diameter $3 \mathrm{~mm}$ dan $4 \mathrm{~mm}$ ternyata ada perbedaannya. Terutama dari sisi ukuran diameter, sangat menentukan bahan stainless tersebut apakah cepat merah terkena panas las atau tidak. Kemudian dari segi kekuatan hasil lasnya dan kekokohan permukaan karya oval yang dihasilkannya, semakin besar diameter bahan stainless-nya maka permukaan lengkung bentuk oval yang dihasilkan lebih kokoh dan untuk dipapras dengan mesin gerinda hasilnya lebih bagus dan tidak mudah bengkok. Bidang datar pada as stainless steel akibat pemaprasan hasilnya lebih luas sehingga saat dipoles hasilnya lebih menarik.

Penggunaan ukuran diameter elektroda busur las juga cukup penting, disesuaikan dengan tujuan pengelasan apakah untuk penggunaan pengelasan titik (elektroda las stainless 1,6 mm), atau las yang sifatnya lebih luas dan memperkuat sambungan (elektroda las stainless $2 \mathrm{~mm}$ ). Merek elektroda busur las yang digunakan juga cukup berpengaruh, terutama merek-merek elektroda yang menunjukan kualitas dari elektroda tersebut. Merek yang sudah terkenal dengan kualitas saat proses dan hasil pengelasan, biasanya harga lebih mahal, namun proses pengelasan lebih mudah, lancar, tidak mudah lengket, dan hasil kerak mudah terkelupas dengan sendirinya, serta asap las yang dihasilkan tidak banyak sehingga tidak perih di mata.

Cetakan resin dan serat kaca sebagai cetakan pola untuk pengelasan harus memiliki tebal yang cukup agar tahan terhadap api dan suhu panas akibat proses pengelasan. Ketebalan cetakan harus terbentuk akibat penerapan lembaran-lembaran serat kaca (fiberglass) yang disisipkan pada setiap tahap 
pelapisan cetakan. Semakin banyak lapisan cetakan yang disisipkan lembaran serat kaca, maka akan semakin kuat bahan cetakan terhadap resiko retak akibat api dan suhu yang sangat panas dari proses pengelasan. Pada contoh eksperimen kali ini, cetakan menggunakan 4 lapis cetakan dimana lapisan 1 adalah lapisan dasar yang tidak disisipkan serat kaca, sedangkan lapisan 2 sampai 4 selalu disisipkan lembaran serat kaca. Dan terbukti cetakan tahan terhadap api dan suhu panas.

Disarankan saat menggunakan teknik las busur agar selalu mencoba dahulu di media logam lain (jangan langsung di karya) untuk memastikan besar arus listrik yang digunakan apakah sudah sesuai dengan diameter elektroda yang akan digunakan. Semakin besar setelan arus listrik yang digunakan akan semakin besar api busur las yang keluar. Semakin kecil setelan arus listrik yang digunakan akan semakin kecil juga api busur las yang keluar. Dampaknya jika arus kecil dan api kecil, proses pengelasan akan sering lengket antara busur las ke bahan yang dilas, dan harus buru-buru dilepas pegangan busurnya. Dan ini sangat menghambat kelancaran proses pengelasan. Sebaliknya jika arus terlalu besar dan api mudah besar, bahan akan cepat leleh. Untuk bahan yang tergolong kecil sperti as stainless steel $3 \mathrm{~mm}$ ini, bahan yang dilas akan cepat putus karena panas sehingga merusak hasil pengelasan, dan elektrodanya akan cepat habis dengan kualitas hasil las yang tidak bagus.

\section{Analisis dan temuan pada tahap akhir: Assembling:}

Pada bagian assembling (perakitan) ini, kegiatan lebih untuk memperkuat dan merapihkan bekas las titik saat 'pengelasan pada cetakan'. Sehingga lebih efektif menggunakan elektroda stainless dengan ukuran diameter $2 \mathrm{~mm}$. Hasil las cepat terisi penuh pada bagian-bagian sambungan, sehingga pengelasan bisa lebih cepat jika menggunakan elektroda yang lebih kecil. Namun juga hati-hati, karena ukuran besar dan dampaknya juga besar, jadi harus cepat dan tepat memberikan sentuhan pengelasan antara elektroda dan benda kerja.

\section{Finishing:}

Dari hasil eksperimen pengelasan, untuk finishing ini langkah-langkahnya masih bersifat fleksibel antara dibersihkan dulu dengan gel pembersih stainless steel atau dipapras dulu dengan mesin gerinda. Sementara pada riset ekperimen kali ini, untuk proses membersihkan hasil pengelasan dengan menggunakan gel pembersih stainless steel lebih dahulu dilakukan. Dilanjutkan pencucian dengan air, selanjutnya setelah kering baru masuk proses pemaprasan permukaan as stainless steel pada permukaan lengkung oval. Namun setelah dianalisa dan dipelajari karakter bahan stainless steel, urutan langkah ini bisa dibalik. Proses pemaprasan dilakukan lebih dulu, selanjutnya baru masuk proses pembersihan dengan gel pembersih stainless steel, dan dicuci pakai air bersih. Mengapa demikian, karena saat proses pemaprasan, hasil pengelasan sebelumnya yang masih kotor dan berwarna hitam gosong, tidak berpengaruh pada proses pemaprasan dengan mesin gerinda. Bahan masih tetap kotor, namun sudah bisa dipapras, dan hasil paprasan juga tetap datar dan tidak terpengaruh. Hanya saja dampak dari pemaprasan tadi, yang kadang menghasilkan gesekan sangat panas, menyebabkan bahan stainless steel tetap kotor. Setelah proses pemaprasan permukaan as stainless steel pada permukaan lengkung oval selesai dikerjakan semua, sesuai hasil yang 
diharapkan, selanjutnya masuk tahap pembersihan stainless steel dengan gel pembersih sesuai prosedurnya, dan diakhiri dengan mencucinya menggunakan air bersih. Selanjutnya baru masuk proses pemolesan.

Pemolesan harus dilakukan berulangulang pada beberapa area yang sama dengan menggunakan mata gerinda kain jeans poles dan bahan batu hijau poles yang sering disebut langsol. Tanpa bahan langsol ini, proses poles tidak akan berhasil mengkilap walaupun sudah dilakukan berulang-ulang. Hal ini disebabkan karena batu hijau langsol memiliki kemampuan mengikis yang rendah pada permukaan logam, khususnya stainless steel.

Sedangkan pada bahan gel pembersih stainless steel, karena larutan gel ini merupakan larutan kimia yang tergolong keras, sebaiknya harus menggunakan sarung tangan karet, masker pelindung hidung, dan kacamata pelindung mata dari uap reaksi kimia larutan asam yang cukup bikin mata merasa pedas.

\section{HASIL}

Hasil riset teknik las busur ini telah berhasil menciptakan satu karya 3 dimensi berbentuk oval dengan permukaan lengkung dari bahan as stainless steel.

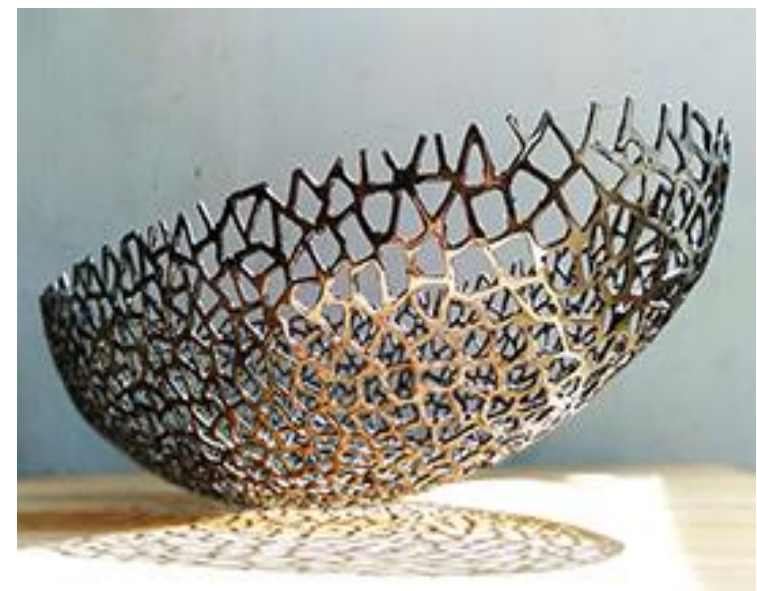

Karya oval dengan posisi menengadah (dokumen pribadi, 2020)
Hasil riset ini, oleh penulis juga sudah coba untuk digabungkan dengan bahan lain, sebagai salah satu pengembangan hasil penelitian.

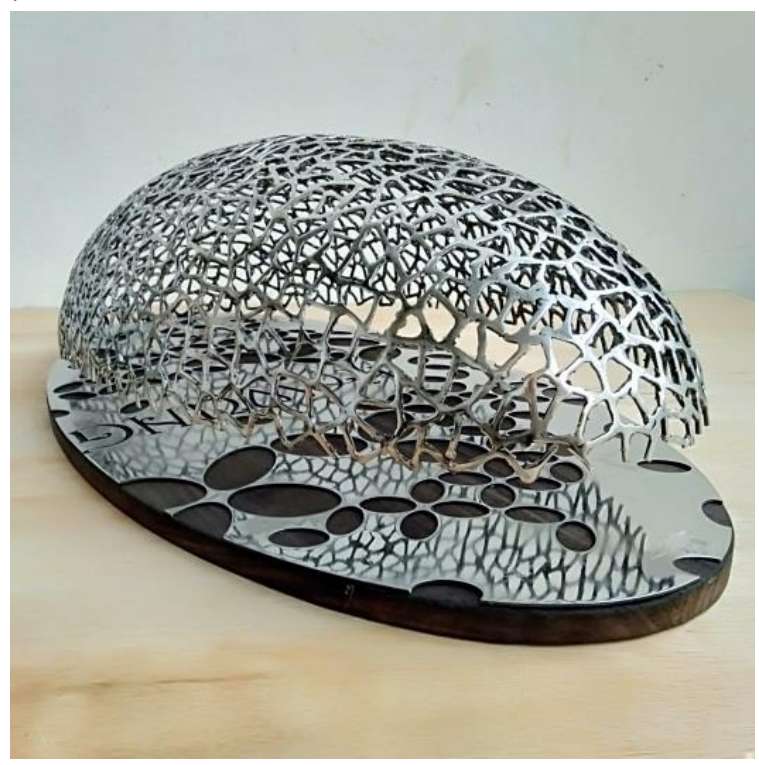

Pengembangan hasil penelitian yang dikombinasikan dengan kayu mahogany dan plat stainless steel 304. Judul karya: the Soul of Kawung. (dokumen pribadi, 2020)

\section{SIMPULAN}

Bahan-bahan dan peralatan-peralatan yang digunakan pada keseluruhan riset ini sudah diketahui, teridentifikasi, dan dicoba langsung dalam riset praktik eksperimental.

Terkait tata-cara menggunakan peralatan yang ada beserta cara mengaplikasikan pada bahan-bahan agar proses pengelasan dapat berjalan dengan baik dan efektif, salah satunya adalah pemilihan bahan as stainless steel yang direkomendasikan adalah diameter $4 \mathrm{~mm}$, karena lebih kokoh, kuat, dan kalau dipapras bidang datarnya relatif cukup lebar dan bagus untuk dipoles. Sedangkan untuk elektroda yang digunakan sebaiknya elektroda yang sudah memiliki merek dan terkenal bagus kualitasnya. Kualitas elektroda sangat mempengaruhi kelancaran proses pengelasan dan hasil pengelasannya juga lebih 
baik, kerak las biasanya lepas dengan sendirinya.

Sedangkan untuk tahap-tahap pelaksanaan proses pengelasan mulai dari tahap persiapan, tahap pengerjaan, dan tahap akhir, harus dilakukan secara berurutan agar didapat hasil yang maksimal. Diusahakan dalam setiap tahap pelaksanaan harus dikerjakan secara teliti dan tertib aturan. Harus menggunakan perlengkapan peralatan keselamatan kerja, mulai dari mata, hidung, tangan, muka, dan kulit secara keseluruhan. Menggunakan perlengkapan peralatan keselamatan kerja adalah wajib dan tidak boleh disepelekan.

Temuan terakhir adalah bahwa karya mengalami penyusutan yang cukup signifikan dari model oval berbahan gypsum dan kalsit, ke karya oval dari bahan as stainless steel. Untuk hasil riset kali ini perbedaan penyusutan sekitar 1-2 cm. Atau mengalami penyusutan sekitar 2,5\% dari ukuran model awalnya.

\section{Saran}

Saran untuk perkembangan lebih lanjut meliputi:

Pertama, penggunaan bahan as stainless steel yang ditentukan cukup satu ukuran, misal: diameter $4 \mathrm{~mm}$ saja, hal ini dilakukan agar proses pengerjaan dapat lebih fokus ke pengembangan bentuk lainnya yang lebih unik, berbeda, dan bahkan lebih kompleks, misal: bentuk stilasi binatang atau tumbuhan.

Kedua, rapat renggang dari sambungansambungan bahan as stainless steel bisa lebih dimainkan variasinya, atau bahkan diatur kerapatannya hingga hampir tidak ada celah dan dikombinasikan dengan yang sambungan renggang, sehingga berpotensi menciptakan kesan tekstur permukaan karya yang unik, saling kontras, dan estetik.
Ketiga, penerapan bahan as stainless steel ke bentuk lain yang lebih fungsional, seperti kursi, sofa, lampu dinding, lampu meja, dan kriya logam lainnya.

\section{DAFTAR PUSTAKA}

Alip M. (1989). Teori dan Praktik Las. Proyek Pengembangan Lembaga Pendidikan Tenaga Kependidikan Jakarta.

Arifin S. (1997). Las Listrik dan Otogen. Ghalia Indonesia.

\section{Bintoro, G. A. (1999). Dasar-Dasar Pekerjaan} Las, Jilid 1. Penerbit Kanisius.

Daniel, L. L. (2018). Eksplorasi dan Penggabungan Mesin Pada Seni Patung. Jurnal Corak, 7(2), 139-148. http://journal.isi.ac.id/index.php/corak/art icle/view/2678

Daryanto. (2012). Teknik Las. Alfabento.

Gay, L. R. (1981). Educational Research: Competencies for Analysis and Application. Prentice-Hall International (UK) Itd.

Mills, J. (1990). The Encyclopedia of Sculpture Techniques. B.T. Batsford Ltd.

Nasrul, M. Y., Suryanto, H., \& Qolik, A. (2016). Pengaruh Variasi Arus Las SMAW Terhadap Kekerasan dan Kekuatan Tarik Sambungan Dissimilar Stainless Steel 304 dan ST 37. Jurnal Teknik Mesin, 24(1), 112.

http://journal2.um.ac.id/index.php/jurnalteknik-mesin/article/viewFile/511/324

Nuning. W., M. M. (2015). Metode Penciptaan Bidang Seni Rupa: Praktek Berbasis Penelitian (practice based risearch), Karya Seni Sebagai Produksi Pengetahuan dan Wacana. CORAK, 4(1). https://doi.org/10.24821/corak.v4i1.2358 
Ruukki. (2007). Resistance Welding Manual. Rautaruukki Corporation.

Verhelst, W. (1988). Sculpture: Tools, Materials, and Techniques (2nd ed.). Prentice Hall Inc.

Wiryosumarto, H., \& Okumura, T. (2000).

Teknologi Pengelasan Logam. PT. Pradnya Paramita.

Acuan dari dokumen online (website/internet)

http://asm.matweb.com/search/SpecificMateria l.asp?bassnum=mq304a

http://www.astm.org/Standards/steelstandards.html

https://www.nytimes.com/2008/04/22/arts/de sign/22koon.html 